\title{
COUNTRY CHECKLIST OF RHAGOLETIS LOEW (DIPTERA: TEPHRITIDAE) FOR EUROPE, WITH FOCUS ON R. BATAVA AND ITS RECENT RANGE EXPANSION
}

\author{
Arturs Stalažs ${ }^{1, \#}$ and Maksims Balalaikins ${ }^{1,2}$ \\ ${ }^{1}$ Institute of Horticulture, Latvia University of Agriculture, Graudu iela 1, Ceriṇi, Krimūnu pagasts, Dobeles novads, LV-3701, LATVIA \\ ${ }^{2}$ Institute of Life Sciences and Technologies, Daugavpils University, Parādes iela 1A, Daugavpils, LV-5401, LATVIA; \\ maksims.balalaikins@biology.lv \\ \# Corresponding author, arturs.stalazs@llu.Iv
}

Communicated by Viesturs Melecis

This work is intended as a country checklist of fruit flies Rhagoletis Loew, 1862 for Europe (including transcontinental countries - Kazakhstan and Turkey), based on recent records, wherein we recognise 15 Rhagoletis species, including five species occurring in the Asian part of Kazakhstan. During the past 10-15 years, three species, Rhagoletis batava Hering, 1958, R. cingulata (Loew, 1862), and R. completa Cresson, 1929, have rapidly expanded their distribution range in Europe. We traced the potential route of an aggressive R. batava population movement into Europe, and it is postulated that this $\mathrm{R}$. batava race originated from Siberia. $\mathrm{R}$. batava was initially documented outside its natural range in 2001 in the European part of the Russian Federation. Later, this species was recorded in other territories to the west of Russia - Belarus (2010), Latvia (2011), Lithuania (2012), Germany (2013), and Poland (2014). In Germany and Poland, R. batava probably has both native and alien status.

Key words: alien species, fruit flies, population expansion, sea buckthorn pest.

\section{INTRODUCTION}

The number of Rhagoletis Loew, 1862 (Tephritidae: Trypetinae) species is relatively large, and more then 60 species are described worldwide (Christian Thompson, 1998). There has been great interest in fruit flies over many years because of their importance as pests. Rhagoletis flies are important, as many species of this genus are harmful to fruit-plant species with economic importance (White and Elson-Harris, 1992; Alford, 2007). Two species, Rhagoletis cingulata (Loew, 1862) and $R$. completa Cresson, 1929, native to North America, were accidentally introduced into Europe, and rapid expansion of both species has been observed during the last two decades (Anonymous, 2014a, Anoymous, 2014d). At the same time, another important species, Rhagoletis batava Hering, 1958, a pest of seabuckthorn, rapidly expanded in central - eastern European countries, where it has significant economic importance in sea buckthorn production (Höhne and Gießmann, 2013; Höhne, 2014; Rupais et al., 2014; Stalažs, 2014a; Stalažs, 2014b; Brūvelis and Shalkevich 2014, pers. comm.).

The literature on fruit flies is extensive; however there are no compilations on the distribution of European Rhagoletis on a per-country basis. European Food Safety Authority
(EPSA) published the most recent work with data on the European distribution of Rhagoletis cingulata (Anonymous, 2014d). The Fauna Europaea database project includes data on nine Rhagoletis fruit fly species (Korneyev, 2011), but distribution information for each country is highly incomplete. Some studies dealing with fruit flies, especially the most comprehensive ones, e.g., Hendel (1927), Rihter (1970), and Christian Thompson (1998) in many cases provide insight into species distribution for wider regions, e.g., Europe, central zone of western Europe, western Europe, Palaearctic, etc. This may be acceptable for widely distributed species, for example, for Rhagoletis alternata (Fallen, 1814), R. cerasi (Linnaeus, 1758), and R. meigenii (Loew, 1844), but when it is necessary to complete checklists for specific countries this information is not always useful. This is especially important when there is a need to know confirmed distributions for particular countries or for smaller territories where there may be only a few confirmed localities.

Sometimes wide species range information can be misleading, if precise distribution data is necessary. For example, Rihter (1970) provides European distribution data for Rhagoletis flavicincta Enderlein, 1934 as follows: central zone of Western Europe, but in Europe presence of this species 
has been confirmed only in two countries, e.g., European part of the Russian Federation, and Ukraine (Mohamadzade Namin and Rasoulian, 2009; Korneyev, 2011), where Rhagoletis flavicincta has local distribution.

For those studying the biology of species, especially invasion ecology and biodiversity changes, it is important to know species distribution range change over time. This can be especially important for understanding the ecology of an expanding species. For forecasting the species distribution changes in the future, knowledge about the initial distribution range and dispersal possibilities of species are important tools and more precise initial data are needed.

During the international conference EuroWorkS 2014, which took place at Naantali (Finland), Rhagoletis batava was described as the most important sea buckthorn pest. As this pest is highly important for the sea buckthorn industry, a special international working group of seven members from six European countries dealing with this pest was created. Before developing strategies to deal with this pest, it was necessary to understand and delineate the exact distribution range and behavioural changes for Rhagoletis batava.

The main object of this publication is to provide documented information on Rhagoletis batava. The objective of the work is to assess the current situation of Rhagoletis fruit fly distribution in European countries, especially for rapidly expanding species, e.g., Rhagoletis batava, Rhagoletis cingulate, and Rhagoletis completa. In this publication we attempted to track the potential route of an aggressive Rhagoletis batava population into Europe.

\section{EXPANSION OF RHAGOLETIS BATAVA, A PEST OF SEA BUCKTHORN}

On the basis of available sources of information on Rhagoletis batava we tracked the possible route of a population of Rhagoletis batava, an aggressive and economically important pest of sea buckthorn, into Europe.

Initially this species was described in The Netherlands (Hering, 1958) and for a long time Rhagoletis batava was known only in a few European countries. For years this species has been a serious pest of common seabuckthorn (Hippophae rhamnoides) in Western Siberia and Altai Region (Kolomiec, 1970; Shamanskaya, 2006) and was not known as an important pest in European countries. Expansion of an aggressive population of Rhagoletis batava in Europe was observed starting in 2001 in the European part of the Russian Federation (Drozdovskij, 2002; Dem'ānova et al., 2007; Bogomolova, 2009). Later this species became a serious problem for sea buckthorn growers in Belarus (Shalkevich, 2014, pers. comm.), Latvia and Lithuania (Rupais et al., 2014; Stalažs, 2014a), Germany (Höhne and Gießmann, 2013) and Poland (Brūvelis 2014, pers. comm.) (Fig. 1). In 2015, larvae of Rhagoletis batava were recorded in two sea buckthorn farms in Estonia and Finland (Brūvelis and Kauppinen 2015, pers. comm.) and adult flies were caught during monitoring in Hungary (Vétek, 2015, unpublished data).

All signs show that this expansive race of Rhagoletis batava spread to Europe from Siberia (Fig. 1), but there is no answer to why the Siberian population is more aggressive and harmful to sea buckthorn than the European one. In 1970, Siberian flies were described as a new subspecies, Rhagoletis batava obscuriosa (Kolomiec, 1970 (original spelling of the authors name was Kolomyetz). Kolomiec believed that the Siberian population was a separate subspecies and described several morphological differences between Siberian and European flies. This subspecies name is widely used by Russian sea buckthorn growers and scientists. However, in the world register of fruit flies (Christian Thompson, 1998), this taxon is listed as a separate species - Rhagoletis obscuriosa Kolomietz, 1970, not as a subspecies, as it is in the original description made by Kolomiec. There is no evidence for the acceptance of a separate Siberian subspecies, and future research is necessary, but we suggest that expansion of Rhagoletis batava in Europe started from Siberian populations. This means that there are some factors that help the Siberian population to be more aggressive and better adapted for dispersal. It is highly believable that the range expansion of fruit flies during recent years is driven by climate changes. As common sea buckthorn, the $R$. batava food source, is also distributed in other countries where this fly species has not been previously recorded (see Fig. 2), probably native European populations of $R$. batava are more widely distributed than currently known. As common sea buckthorn is also native to Germany, it is highly believable that now $R$. batava has both native and alien status in this country. This also may be the case for Poland.

\section{IMPORTANCE OF RHAGOLETIS BATAVA IN EUROPE}

As it was mentioned above, for a long time there was no important noteworthy damage to sea buckthorn in European countries. In contrast to the situation in Europe, in Western

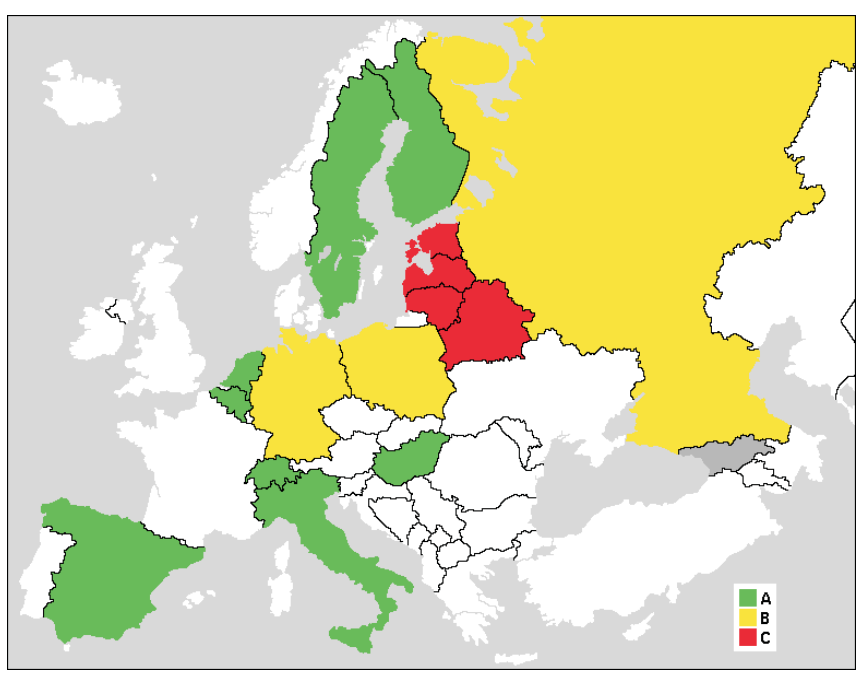

Fig. 1. European distribution of Rhagoletis batava: A, native, B, native and probably also alien, $\mathbf{C}$, alien. For other countries no data are available. 


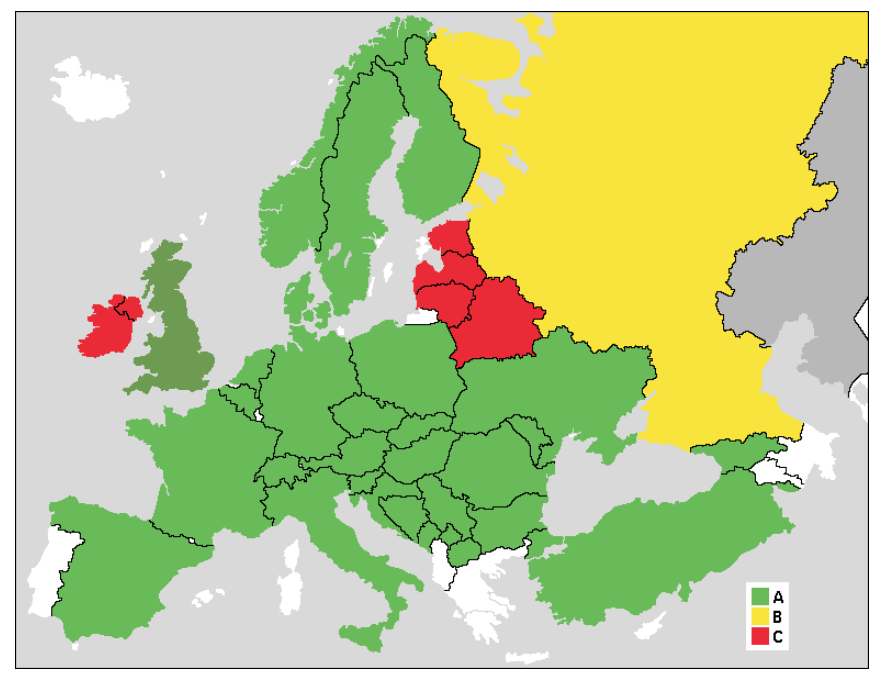

Fig. 2. European distribution of Hippophae rhamnoides - the host plant for Rhagoletis batava: A, native, B, native and alien, C, alien. For other countries no data are available.

Siberia and Altai Region problems with Rhagoletis batava are known for long time (Kolomiec, 1970; Shamanskaya, 2006; Shamanskaya, 2014, pers. comm.). Only around 2010, important damage of sea buckthorn fruit was reported from parts of Europe close to Baltic Sea region, e. g. Belarus (Shalkevich, 2014, pers. comm.) and Germany (Höhne and Gießmann, 2013). The amount and nature of damage observed in Germany (Höhne and Gießmann, 2013; also Fig. 3) is identical to that previously reported from Siberia, when larvae of Rhagoletis batava can cause up to $100 \%$ fruit loss. In Latvia, massively damaged fruit crop has been observed locally, especially in the eastern part of the country (Brūvelis, 2016, pers. comm.) and this is associated with Rhagoletis batava flying dynamics (Balalaikins, Stalažs, 2014-2016, unpublished data) of Rhagoletis batava monitoring results.

As on the basis of published sources, it is possible to track the information on expansion of Rhagoletis batava distribution area, with historical data showing migration of Rhagoletis batava "problem" from the European east in the Russian Federation to western territories; there is reason to postulate that the more aggressive Rhagoletis batava population initially originated from Siberia is expanding in Europe. This could even support the presumption that Sibe- rian flies is a separate subspecies, made by Kolomiec (1970). However, the further molecular and morphological studies are needed to confirm the existence of the separate subspecies within the Rhagoletis batava.

In Europe, it was mostly considered that sea buckthorn is not associated with important pests, which caused the opinion that this crop does not need integrated growing management, as was adopted in Latvia. The Rhagoletis batava problem most of all is highly important in all European countries where seabuckthorn is cultivated as fruit crop, as there are no officially registered biocides allowed for use against this or other potential pests of sea buckthorn. It is interesting that, despite of importance of sea buckthorn as a highly valuable crop plant, its pests are weakly studied in Europe and Asia. The only exception is in the Altai Region in Siberia, where several pests of sea buckthorn have been studied for a longer time, including on the optimisation of Rhagoletis batava elimination (Shamanskaya, 2006; Shamanskaya, 2006, pers. comm.).

\section{PREPARATION OF COUNTRY CHECKLIST FOR RHA- GOLETIS FLIES IN EUROPE}

For creating of the country checklist of Rhagoletis fruit flies in Europe, we used all available information sources (scientific publications, one database - Fauna Europaea (available at http://www.faunaeur.org), and information from personal communication). Sources of information are cited accordingly for each particular species within the checklist part. Only the original publications explored by the authors are cited. All species are grouped in alphabetical order, according the nomenclature of Christian Thompson (1998) and Korneyev (2011). Distribution of Rhagoletis fruit flies are reviewed for all European countries, including transcontinental Kazakhstan and Turkey.

A checklist with 15 species of Rhagoletis fruit flies was compiled (see Checklist below). Some of the species are distributed only in the Asian part of transcontinental countries, e.g., Kazakhstan, but we decided to also include these species, as we provide a review for the total area of Kazakhstan (not for only a part of the country). Besides the checklist, we prepared also a table (Table 1) that will pro-
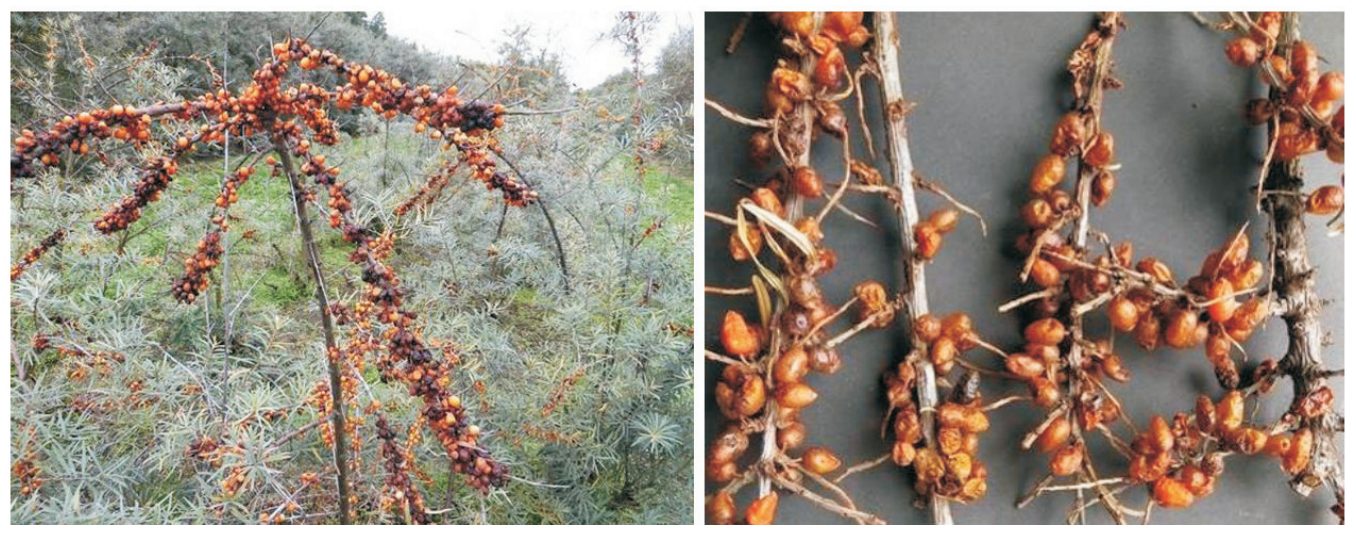

Fig. 3. Seabuckthorn fruit damaged by Rhagoletis batava (photos courtesy from Dr. Jörg-Thomas Mörsel, UBF — Untersuchungs-, Beratungs-, Forschungslaboratorium $\mathrm{GmbH}$, Germany) 
Table 1 OVERVIEW OF RHAGOLETIS DISTRIBUTION IN EUROPEAN COUNTRIES, AND COMPARISON WITH DATA FROM THE FAUNA EUROPAEA DATABASE

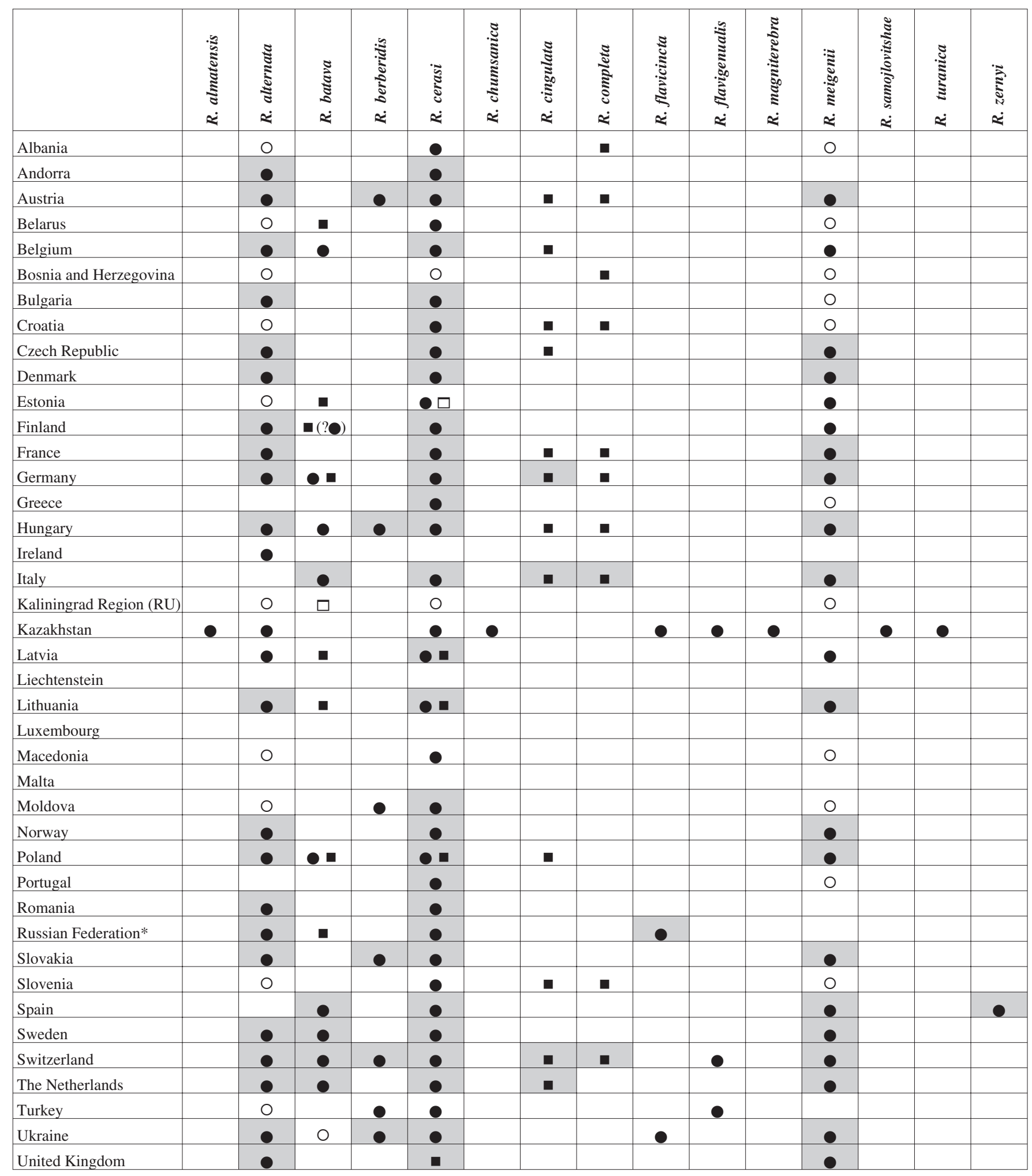

* European part, except Kaliningrad Region

Native distribution:

Alien distribution:

- confirmed for country

- confirmed for country

O no data, but possible in country

$\square$ no data, but possible in country

distribution information available from Fauna Europaea (Korneyev, 2011) 
vide an overview of all species and their country distributions.

Additionally, we compared distribution information available from the Fauna Europaea database (Korneyev, 2011) (see Table 1). The results show highly differing country distribution information for almost all Rhagoletis species covered by Fauna Europaea. According to this database, the most accurate distribution is provided only for Rhagoletis cerasi, which is the most widespread species in the European Continent. The species Rhagoletis flavigenualis Hering, 1958 is recognised as a species occurring in Europe, but it is not included in the Fauna Europaea list of Rhagoletis species.

\section{CHECKLIST OF SPECIES}

\section{Rhagoletis almatensis Rohdendorf, 1961}

Distribution: Central Asia: South-Eastern Kazakhstan; other countries: Kyrgyzstan.

References: Korneyev and Merz, 1997; Christian Thompson, 1998.

Host: Associated with Lonicera spp. (Korneyev and Merz, 1997).

\section{Rhagoletis alternata (Fallén, 1814)}

Distribution: European: Andorra, Austria, Belgium, Bulgaria, Czech Republic, Denmark, Finland, France, Germany, Hungary, Latvia, Lithuania, Norway, Poland, Romania, Russian Federation (European part), Slovakia, Sweden, Switzerland, The Netherlands, Ukraine, and United Kingdom. Species range: from British Islands and Scandinavia south to France, Slovenia, Bulgaria. Non-European: Kazakhstan, Armenia, Altai, southern Siberia, Japan, Kyrgyzstan, Russian Far East.

References: Rihter, 1970; Hedström, 1995; Korneyev and Merz, 1997; Christian Thompson, 1998; Alexander, 2002; Baugnée, 2006; Pakalniškis et al., 2006; Karpa, 2008; Merz and Kofler, 2008; Korneyev, 2011; Arutûnân and Arutûnân, 2012; Rupais et al., 2014; Stalažs, 2014b.

Host: Rosa spp. (Rosa canina Group, Rosa rugosa, Rosa villosa) (Rihter, 1970; White and Elson-Harris, 1992; Baugnée, 2006). Larvae in fruit.

\section{Rhagoletis batava Hering, 1958}

Distribution: European: Belarus, Belgium, Estonia, Finland, Germany, Hungary, Italy, Latvia, Lithuania, Poland, Russian Federation (European part), Spain, Sweden, Switzerland, and The Netherlands. Non European: North-Central Caucasus; Armenia, Kyrgyzstan, Russian Federation (West Siberian plain), and South Siberian mountains: Altai, Tuva.

Remarks: Species is not recorded in Ukraine, but it might occur everywhere where its host plant grows (Korneyev, 2015). Although the host plant occurs in Romania, flies were not detected in this country during monitoring in 2016 (Florin, 2016, pers. comm.). Further monitoring is necessary in all countries where Hippophae rhamnoides grow.

References: Hedström, 1995; Christian Thompson, 1998; Drozdovskij, 2002; Smith et al., 2005; Baugnée, 2006; Shamanskaya, 2006; Bogomolova, 2009; Korneyev, 2011; Arutûnân and Arutûnân, 2012; Höhne and Gießmann, 2013; Höhne, 2014; Rupais et al., 2014; Shalkevich et. al., 2014; Stalažs, 2014a, 2014b; Brūvelis, 2014, 2015, pers. comm.; Kauppinen 2015, pers. comm.; Vétek, 2015, unpublished data.

Host: Hippophae rhamnoides (Rihter, 1970; Baugnée, 2006). Larvae in fruit.

\section{Rhagoletis berberidis Jermy, 1961}

Distribution: European: Austria, Hungary, Moldova, Slovakia, Switzerland, and Ukraine. Non European: Caucasus; Armenia, Turkey;

References: Korneyev, 1997; Christian Thompson, 1998; Kütük, 2008; Mohamadzade Namin and Rasoulian, 2009; Arutûnân and Arutûnân, 2012.

Host: Berberis vulgaris (Rihter, 1970). Larvae in fruit.

\section{Rhagoletis cerasi (Linnaeus, 1758)}

Syn.: Trypeta signata Meigen, 1826

Distribution: European: Albania, Andorra, Austria, Belarus, Belgium, Bulgaria, Croatia, Czech Republic, Denmark, Estonia, Finland, France, Germany, Greece, Hungary, Italy, Latvia, Lithuania, Macedonia, Moldova, Norway, Poland, Portugal, Romania, Russian Federation (European part), Slovakia, Slovenia, Spain, Sweden, Switzerland, The Netherlands, Ukraine, and United Kingdom. Non European: Western Siberia to Caucasus and Central Asia: Armenia, Kazakhstan, north-western Georgia, Turkey, and Iran.

Remarks: The 'Southern' race on cherries is alien in all countries where cherries are non-native plants. During the last 20-30 years, the 'southern' race expanded to the north, e. g. in Baltic countries, where previously problems with flies on cherries were not observed. According to Alford (2007), the 'northern' race is distributed in countries to the north and east of Switzerland.

References: Hedström, 1995; Christian Thompson, 1998; Grichanov and Ovsyannikova, 2003-2009; Korneyev, 2003; Karpa et al., 2005; Baugnée, 2006; Pakalniškis et al., 2006; Alford, 2007; Karpa, 2008; Merz and Kofler, 2008; Mohamadzade Namin and Rasoulian, 2009; Korneyev, 2011; Arutûnân and Arutûnân, 2012; Bandzo et al., 2012; Daniel and Grunder, 2012; Rupais et al., 2014; Stalažs, 2014b; Anonymous, 2014c; Anonymous, 2014e.

Host: Prunus avium, Prunus cerasus for 'southern' or 'cherry' race, and Lonicera tatarica, Lonicera xylosteum, probably other Lonicera, and sometimes also Symphoricar- 
pos albus for 'northern' race (Rihter, 1970; Alford, 2007). Larvae in fruit.

\section{Rhagoletis chumsanica (Rohdendorf, 1961)}

Distribution: Southern Kazakhstan, other countries: Kyrgyzstan.

References: Korneyev and Merz, 1997; Christian Thompson, 1998

Host: Unknown.

\section{Rhagoletis cingulata (Loew, 1862)}

Distribution: European (introduced): Austria, Belgium, Croatia, Czech Republic, France, Germany, Hungary, Italy, Poland, Slovenia, Switzerland, and the Netherlands. Non European: North America: Canada, central Mexico, and United States.

References: Christian Thompson, 1998; Baugnée, 2006; Alford 2007; Skuhravị et al., 2010; Korneyev, 2011; Anonymous, 2014a; 2014d; $2014 \mathrm{f}$.

Host: Prunus avium, Prunus cerasus, Prunus padus, Prunus serotina (Baugnée, 2006; Alford, 2007). Larvae in fruit.

\section{Rhagoletis completa Cresson, 1929}

Distribution: European: Albania, Austria, Bosnia and Herzegovina, Croatia, France, Germany, Hungary, Italy, Slovenia, and Switzerland. Non European: North America: Mexico and United States (native: Minnesota to Nuevo Leon and Mississippi; alien: Washington and Utah to California).

References: Christian Thompson, 1998; Alford, 2007; Korneyev, 2011; Anonymous, 2014b; 2014c.

Host: Juglans spp. (Alford, 2007). Larvae in fruit skin.

\section{Rhagoletis flavicincta Enderlein, 1934}

Distribution: European: Russian Federation (European part), and Ukraine.

Non European (species range): from Ukraine and Russian Federation (central-southern European Part) to Kazakhstan and Central Asia (Armenia, Iran, Kyrgyzstan, Tajikistan, and Uzbekistan.

References: Christian Thompson, 1998; Mohamadzade Namin and Rasoulian, 2009; Korneyev, 2011; Arutûnân and Arutûnân, 2012.

Host: Lonicera caerulea var. dependens (syn. Lonicera stenantha), Lonicera tatarica (Rihter, 1970). Larvae in fruit.

\section{Rhagoletis flavigenualis Hering, 1958}

Distribution: European: Switzerland, and Turkey. Non European: Armenia, north-western Iran, Kazakhstan, southern Kyrgyzstan, Tajikistan, and southern Turkmenistan.
References: Korneyev and Merz, 1997; Ribera and BlascoZumeta, 1998; Smith et al., 2005-2006; Mohamadzade Namin and Rasoulian, 2009; Arutûnân and Arutûnân, 2012.

Host: Juniperus excelsa, Juniperus foetidissima, Juniperus sabina, Juniperus seravschanica, and other Juniperus (Rihter, 1970; White and Elson-Harris, 1992; Ribera and Blasco-Zumeta, 1998; Mohamadzade Namin and Rasoulian, 2009). Larvae in fleshy cones.

\section{Rhagoletis magniterebra (Rohdendorf, 1961)}

Distribution: Southern Kazakhstan; other: Central Asia, Kyrgyzstan, and northern Tajikistan.

References: Korneyev and Merz, 1997; Christian Thompson, 1998.

Host: Larva in Berberis heteropoda (Korneyev and Merz, 1997)

\section{Rhagoletis meigenii (Loew, 1844)}

Distribution: European: Austria, Belgium, Czech Republic, Denmark, Estonia, Finland, France, Germany, Hungary, Italy, Latvia, Lithuania, Norway, Poland, Slovakia, Spain, Sweden, Switzerland, The Netherlands, Ukraine, and United Kingdom. Non European: Caucasus: Armenia, Central Asia; introduced to Canada (Nova Scotia) and United States (Maine, and New Hampshire).

References: Hedström, 1995; Korneyev and Merz, 1997; Christian Thompson, 1998; Baugnée, 2006; Pakalniškis et al., 2006; Karpa, 2008; Merz and Kofler, 2008; Korneyev, 2011; Arutûnân and Arutûnân, 2012; Kahanpää and Winqvist, 2014; Rupais et al., 2014; Stalažs, 2014b; Anonymous, $2014 \mathrm{f}$.

Host: Berberis vulgaris (Rihter, 1970; Baugnée, 2006). Larvae feed on fruit seeds.

\section{Rhagoletis samojlovitshae (Rohdendorf, 1961)}

Distribution: Southern Kazakhstan; other: Kyrgyzstan.

References: Korneyev and Merz, 1997; Christian Thompson, 1998.

Host: Larvae in Juniperus (Korneyev and Merz, 1997).

\section{Rhagoletis turanica (Rohdendorf, 1961)}

Distribution: Southern Kazakhstan; other distribution: Kyrgyzstan

References: Korneyev and Merz, 1997; Christian Thompson, 1998.

Host: Unknown

15. Rhagoletis zernyi Hendel, 1927

Distribution: Spain. 
Remarks: Species is associated with Spain as an "endemic" (Merz and Blasco-Zumeta, 1995; Christian Thompson, 1998; Ribera and Blasco-Zumeta, 1998; Korneyev, 2011) where Rhagoletis zernyi is dependent on its host plant Juniperus thurifera. Arutûnân and Arutûnân (2012) reported Rhagoletis zernyi also for Armenia.

References. Merz and Blasco-Zumeta, 1995; Christian Thompson, 1998; Ribera and Blasco-Zumeta, 1998; Korneyev, 2011

Host. Juniperus thurifera (Merz and Blasco-Zumeta, 1995). Larvae feed on fleshy cones.

\section{ACKNOWLEDGEMENTS}

The research was supported by the project „Scientific and technological developments for sustainable cultivation and comprehensive use of sea buckthorn (2014-2017). Authors thank all those who provided information on Rhagoletis batava, and helped with the oldest literature - Andrejs Brūvelis (Latvia), Stoian C. Florin (Romania), Sanna Kauppinen (Finland), Valery A. Korneyev (Ukraine), JörgThomas Mörsel (Germany), Maria S. Shalkevich (Belarus), Lubov D. Shamanskaya (Russian Federation), and Gabor Vétek (Hungary).

\section{REFERENCES}

Alexander, K. N. A. (2002). Rhagoletis alternata (Fallén) (Diptera: Tephritidae): The rose-hip fly, new to Ireland. The Irish Naturalists' Journal, 27 (2), 76.

Alford, D. V. (2007). Pests of Fruit Crops. Academic Press, Boston (MA). $461 \mathrm{pp}$.

Anonymous (2014a). Rhagoletis cingulata. CABI. Available at: http://www.cabi.org/isc/datasheet/47051 (last modified: 17 January 2014) (accessed 27 October 2014).

Anonymous (2014b). Rhagoletis completa. CABI. Available at: http://www.cabi.org/isc/datasheet/47053 (last modified: 14 August 2014) (accessed 27 October 2014).

Anonymous (2014c). Delivering Alien Invasive Species in Europe (DAISIE). Available at: http://www.europe-aliens.org (accessed 27 October 2014)

Anonymous (2014d). Scientific opinion on the pest categorisation of Rhagoletis cingulata (Loew). EFSA Journal, 12 (10), [article] 3854.

Anonymous (2014e). Estonian Species Registry (eBiodiversity). Available at: http://iris.ut.ee/elurikkus/search_er.php?ut1=Rhagoletis\&lang=eng (accessed 25 October 2014).

Anonymous (2014f). First report of Rhagoletis cingulata in the Czech Republic. EPPO Reporting Service, 10, 6-7.

Arutыnвn, G. A., Arutыnвn, R. G. (2012). On the fauna of tephritid flies (Diptera, Tephritidae) damaging trees and shrubs in xerophylous sparse-forests of Armenia [Арутюнян, Г. А., Арутюнян, Р. Г. К фауне мух-пестрокрылок (Diptera, Tephritidae), повреждаюхсщих деревья и кустарники в ксерофильных редколесьях Армении]. In: XIV съезд Руского энтомологического общества, Galanika, St-Peterburg, p. 31 (in Russian).

Bandzo, K., Popovska, M., Bandzo, S. (2012). Influence of the time of first fruit color change and the duration of the fruit ripening of the cherry varieties on the infestation by $R$. cerasi. Agroznanje, 13, 39-46.
Baugnée, J.-Y. (2006). Contribution ą la connaissance des Tephritidae de Belgique (Diptera: Brachycera). Notes fauniques de Gembloux, 59, 63-113.

Bogomolova, N. I. (2009). Resistance of cultivars and forms of seabuckthorn against seabuckthorn fruit fly (Rhagoletis batava obscuriosa Kol.) in conditions of middle region of Russia [Богомолова, Н. И. Устойчивость сортов и форм облепихи к облепиховой мухе (Rhagoletis batava obscuriosa Kol.) в условиях средней полосы России]. Аграрныц Вестник Урала [Agrarnyj Vestnik Urala] (10), 27-30 (in Russian).

Christian Thompson, F. (Ed.) (1998). Fruit fly expert identification system and systematic information database: A resource for identification and information on fruit flies and maggots, with information on their classification, distribution and documentation. In: Myia, Vol. 9. Backhuys Publishers, Leiden. 524 pp.

Daniel, C., Grunder, J. (2012), Integrated management of European cherry fruit fly Rhagoletis cerasi (L.): Situation in Switzerland and Europe. Insects, 3, 956-988.

Dem' вnova, E. I., Kvitkina, A. K., Lykov V. A. (2007). Pollination characteristics of Heracleum sibiricum L. and Seseli libanotis (L.) Koch (Арiaceae) at near Ural region [Демьянова, Е. И., Квиткина, А. К., Лыков, В. А. Особенности опыления Heracleum sibiricum L. и Seseli libanotis (L.) Koch (Apiaceae) в Приуралье]. Вестник Пермского университета, Биология [Vestnik Permskogo universiteta, Biologiв], 5 (10), 6-14 (in Russian).

Drozdovskij, Л. М. (2002). Distribution area of seabuckthorn fruit fly expandes [Дроздовский, Э. М. Ареал облепиховой мухи расщиряется]. Защзита и карантин растений [Za?ita i karantin rastenij], (5), 5 (in Russian).

Grichanov, I. Ya., Ovsyannikova, E. I. (2003-2009). Rhagoletis cerasi (Linnaeus) - European cherry fruit fly. Available at:

http://www.agroatlas.ru/en/content/pests/Rhagoletis_cerasi/ (accessed 3 November 2014).

Hedström, L. (1995). Swedish insect finds - report 8. Entomologisk Tidskrift, 116 (3), 101-117 (in Swedish).

Hendel, F. (1927). 49. Trypetidae. In: Lindner, E. (Ed.) Die Fliegen der palaearktischen Region. 5 (Lfg. 16-19). Schweizerbartsche Verlag, Stuttgart, 1-221 + I-XVII pl.

Hering, E. M. (1958). Zwei neue palaarktische Rhagoletis (Dipt., Trypet.). Stuttgarter Beiträge zur Naturkunde, 7: 1-4.

Höhne, F. (2014). Overview of cultivation technologies and their challenges. In: Abstract book of the $3^{\text {rd }}$ European Workshop on Sea Buckthorn EuroWorkS2014, Naantali, Finland October 14-16 2014, MTT, p. 10.

Höhne, Fr., Gießmann, H.-J. (2013). Ein neuer Schädling bedroht den Sanddornanbau massives Auftreten in Versuchen der Landesforschungsanstalt 2013! Info-Blatt, 22 (5), 280-285.

Kahanpää, J., Winqvist, K. (2014). Checklist of the Diptera superfamilies Tephritoidea and Sciomyzoidea of Finland (Insecta). ZooKeys, 441, 259-275.

Karpa, A. (2008). Catalogue of Latvian flies (Diptera: Brachycera). Latvijas Entomologs, 46, 4-43.

Karpa, A., Korneyev, V. A., Kameneva, E. P. (2005). Materials on Latvian Diptera (Brachycera). Latvijas Entomologs, 42, 65-74.

Kolomiec, N. G. (1970). New subspecies of Rhagoletis batava Hg. (Diptera, Tephritidae) from Siberia [Коломиец, Н. Г. Новый подвыд Rhagoletis batava Hg. (Diptera, Tephritidae) из Сибири]. Новые $и$ малоизвестные виды фауны Сибири [Novye i maloizvestnye vidy fauny Sibiri], 3, 40-52 (in Russian).

Korneyev, V. O. (1997). Rhagoletis berberidis (Diptera, Tephritidae, Trypetinae) - first report from Ukraine [Корнєєв, В. O. Rhagoletis berberidis (Diptera, Tephritidae, Trypetinae) — перша знахідка в фауні України]. Vestnik zoologii, 31 (5/6), 94-95 (in Ukrainian).

Korneyev, V. A. (2003). New and little-known Tephritidae (Diptera, Cyclorrhapha) from Europe. Vestnik zoologii, 37 (3), 3-12. 
Korneyev, V. A., Merz, B. (1997). A new species of Rhagoletis Loew (Diptera: Tephritidae), with notes on Central Asian species. Zhurnal Ukraпьського ентомологічного товариства [Jоurnal of Ukrainian Entomological Society], 3 (1), 55-64.

Kütük, M. (2008). The fruit fly (Diptera: Tephritidae) fauna of Kayseri and Sivas Provinces with a new record for Turkey. Turkish J. Zool., 32, 271-285.

Merz, B., Blasco-Zumeta, J. (1995). The fruit flies (Diptera, Tephritidae) of the Monegros region (Zaragoza, Spain), with the record of the host plant of Rhagoletis zernyi Hendel, 1927. ZAPATERI Revista aragonesa de Entomologia, 5, 127-134.

Merz, B., Kofler, A. (2008). Fruchtfliegen aus Osttirol und Kärnten (Österreich) (Diptera: Tephritidae). Linzer biologische Beiträge, 40 (2), 1211-1224.

Mohamadzade Namin, S., Rasoulian, G. R. (2009). A review of fruit flies of the genus Rhagoletis (Diptera, Tephritidae) of Iran and bordering countries, with the key to species. Vestnik zoologii, 43, e-25-e-30.

Pakalniškis, S., Bernotienè, R., Lutovinkovas, E., Petrašiūnas, A., Podẻnas, S., Rimšaitė, J., Sæther, O. A., Spungis, V. (2006). Checklist of Lithuanian Diptera. New and Rare for Lithuania Insect Species, Records and Descriptions, 18, 16-154.

Korneyev V. A. (2011). Rhagoletis Loew 1862. In: Pape, T., Beuk, P. (eds.). Fauna Europaea database. Available at:

http://www.faunaeur.org/full_results.php?id=405708 (last modified 23 January 2011) (accessed 22 October 2014).

Ribera, I., Blasco-Zumeta, J. (1998). Biogeographical links between steppe insects in the Monegros region (Aragón, NE Spain), the Eastern Mediterranean, and Central Asia. J. Biogeogr., 25, 969-986.

Rihter, V. A. (1970). [Рихтер, B. A.] Tephritidae (Trypetidae). In: Štakel'berg, A. A., Narčuk, E. P. (eds.). [Opredelitel' nasekomyh
Evropejskoj časti SSSR, Tom 5, vtoraā čast': Dvukrylye, blohi]. [Штакельбер А. А., Нарчук Э. П. Определитель насекомых Европейской части СССР, Том 5, вторая часть: Двукрылые, блохи Nauka, Leningrad, pp. 132-172 (in Russian).

Rupais, A., Stalažs, A., Strelčūns, R. (2014). Kokaugu kaitēkḷu noteicējs pēc bojājumiem augḷārzos un apstādījumos [Keys to identification of pests by injuries to woody plants in fruit-gardens and parks]. Scripta Letonica, 1, 5-221 (in Latvian).

Shalkevich, M. S., Koltun, N. Y., Pleskatsevich, R. I. (2014). Sea buckthorn pests and diseases in Belarus. In: Abstract book of the $3^{\text {rd }}$ European Workshop on Sea buckthorn EuroWorkS2014, Naantali, Finland October 14-16 2014, MTT, p. 26

Shamanskaya, L. D. (2006). Optimisation of phytosanitary of fruit and berry crop plantations in conditions of Altajskogo Кraja [Шаманская, Л Д. Фитосанитарная оптимизация плодовых и ягодных насаждений в условиях Алтайского края]. NIISS im. M. A. Lisavenko, Barnaul. 235 pp. (in Russian).

Skuhravi, M., Martinez, M., Roques, A. (2010), Diptera. BioRisk, 4 (2), 553-602

Smith, J. J., Jaycox, M., Smith-Caldas, M. R. B., Bush, G. L. (2005-2006). Analysis of mitochondrial DNA and morphological characters in the subtribe Carpomyina (Diptera: Tephritidae). Israel J. Entomol., 35-36, 317-340.

Stalažs, A. (2014a). New records of some dipterans (Diptera: Cecidomyidae, Tephritidae) in North-Eastern Lithuania. Zool. Ecol., 24, 55-57.

Stalažs, A. (2014b). New records of Tephritoidea (Diptera: Brachycera) for the fauna of Latvia. Zool. Ecol., 24, 347-351.

White, I. M., Elson-Harris, M. M. (1992). Fruit Flies of Economic Significance: Their Identification and Bionomics. C.A.B. International \& Australian Centre for International Agricultural Research (ACIAR), Wallingford. $601 \mathrm{pp}$.

Received 13 October 2016

Accepted in the final form 15 June 2917

\section{RHAGOLETIS LOEW (DIPTERA: TEPHRITIDAE) SUGU SARAKSTS EIROPAS VALSTİM, AR UZSVARU PAR $R$. BATAVA UN TĀS NESENO AREĀLA EKSPANSIJU}

Nemot vērā jaunākos zinojumus, šis darbs ir gatavots kā Rhagoletis Loew, 1862 raibspārnmušu sugu pārskats Eiropas valstīm, kurā iekḷautas 15 Rhagoletis sugas, ieskaitot piecas sugas, kas sastopamas Kazahstānas Āzijas dạ̣ā. Trim sugām — Rhagoletis batava Hering, $1958, R$. cingulata (Loew, 1862) un $R$. completa Cresson, 1929 pēdējo 10-15 gadu laikā Eiropā ir strauji paplašinājies to izplatības areāls. Esam izsekojuši iespējamo virzienu agresīvās $R$. batava populācijas izplatībai Eiropā, un ir pienemts, ka šì $R$. batava rase cēlusies Sibīrijā. Ārpus dabiskā areāla R. batava sākotnēji dokumentēta 2001. gadā — Krievijas Federācijas Eiropas daḷā. Vēlāk šī suga ir reǵistrēta arī citās teritorijās uz rietumiem no Krievijas - Baltkrievijā (2010), Latvijā (2011), Lietuvā (2012), Vācijā (2013) un Polijā (2014). Ir iespējams, ka Vācijā un Polijā R. batava ir divējāds — vietējs un svešs statuss. 